\title{
China, India and Industrial Policy for Inclusive Growth ${ }^{*}$
}

\author{
Inderjit N. Kaur \\ Nirvikar Singh ${ }^{ \pm}$ \\ University of California, Santa Cruz
}

Revised October 2013

\begin{abstract}
This paper discusses a possible case for industrial policy, with special reference to the two emerging global giants, China and India. It begins with a clarification of the meaning of industrial policy, since not only does the term mean different things to different people, but the traditional and narrow definitions leads to significantly different conclusions than more recent, broader definitions. In the context of definition of the term, the paper also reviews the arguments for and against industrial policy, and discusses industrial policy in the context of globalization, including the evolution of multilateral trading rules. The main arguments of the paper discuss the Chinese and Indian economies, exploring in particular their past experience with variants of industrial policies. The similarities of the "China model” to past East Asian experience are explored, while the contrasts of India's development, and the distinction between liberalization and reform are examined. These two major country cases form the basis for a consolidation of recent conceptual ideas, where effective and successful industrial policy is viewed as part of a social contract, creating a pathway to inclusive growth.
\end{abstract}

JEL Codes: O10, O25, O40, O57, P52

Keywords: Industrial policy, China model, India, inclusive growth, comparative advantage, economic reform

\footnotetext{
* This is a revised version of a project report completed while Inderjit N. Kaur was a Kiriyama Fellow at the USF Center for the Pacific Rim. She gratefully acknowledges their generous financial support of the project. The authors alone are responsible for any opinions expressed or shortcomings in the paper.

${ }^{ \pm}$Corresponding author: Department of Economics, University of California, Santa Cruz, CA, 95064, boxjenk@ucsc.edu.
} 


\section{Introduction}

Even after the fall of communism, the role of the state in promoting economic development remains the subject of lively and evolving debates, particularly with reference to industrial policy. The desirability of industrial policy has been a contentious issue among economists. Economic theory can clearly illustrate the market distorting/interfering effects of industrial policy, or conversely show the market failure conditions under which industrial policy is justified. ${ }^{1}$ The empirical evidence remains mixed and fraught with conceptual and methodological issues. ${ }^{2}$

In fact, it is not difficult to find instances where industrial policies have failed. The more significant point, however, is that it is difficult to find examples of catch-up industrialization where industrial policy has not been widely employed. Across the board, industrial policy has enabled rapid industrial restructuring and growth in almost all economies in their respective catch-up phase. ${ }^{3}$ Kaur (2013) argues that, despite changes in the international economic environment from the time period of the catch-up industrialization of the Northeast Asian economies, the process still rests on sequential upgrading of comparative advantage to higher value-added activities. That paper mentions the need for public policy to enable this process and, following that line of reasoning, the current paper makes a case for industrial policy, with special reference to the two emerging global giants, China and India.

Industrial policy has the potential to directly alter the industrial structure of an economy in desired directions, and since industrial restructuring is at the heart of industrialization-based economic growth, the use of industrial policy will need to continue to be a significant policy tool.

\footnotetext{
${ }^{1}$ For example, see Pack and Saggi (2006) and Rodrik (2007), as well as the references in each of those papers. Theoretical arguments in favor of industrial policy can be based on economy-wide externalities (requiring a "big push,” as well as sector- or industry-specific externalities. The term “externalities” refers to spillover effects that are not adequately incorporated into market prices and valuations, so that market-mediated resource allocation is not optimal. Theoretical arguments against industrial policy typically do not deny the possibility of market "failure,” but are based on the government's inability to do better than the market, either because of lack of information, or because the objectives of government decision makers are not aligned with maximizing societal welfare.

${ }^{2}$ Both Pack and Saggi (2006) and Rodrik (2007) evaluate this empirical evidence and its limitations, from differing perspectives.

3 This includes not only the newly industrialized high-growth Asian economies but, historically, almost all developed countries, as discussed in Chang (2002).
} 
In other words, industrial policy will need to continue to be an integral part of the wider set of government policies. In fact, this paper argues that industrial policy will need to be a central component of policies to achieve the goals of rapid and inclusive development in Asia. The market on its own simply cannot effectively overcome all the externalities involved. A publicprivate partnership will be needed to nurture infant industries, develop industry-specific capabilities and achieve scale and co-ordination.

However the role of industrial policy (as of any policy) will evolve with changes in the domestic and international economic environment - with changes in institutions, technology and human resources, and greater regional integration, new multilateral rules, more competition from emerging nations, and greater proliferation of economic and global production networks. Moreover, the effectiveness of industrial policy will depend on the quality and nimbleness of its design and implementation. ${ }^{4}$

The paper begins with a clarification of the meaning of industrial policy. This is a crucial step in the discussion, since not only does the term mean different things to different people, but the traditional and narrow definitions leads to significantly different conclusions than the more recent and relevant definitions. In the context of definition of the term, the paper also reviews the arguments for and against industrial policy, with emphasis on recent viewpoints. The next section discusses industrial policy in the context of globalization, including the evolution of multilateral trading rules. The historical experience of Northeast Asia is brought to bear on the discussion of global trading rules, because it has been argued that the evolution of those rules may not permit today's developing economies the same latitude. This section also touches on the implications for capital controls and financial liberalization, of pursuing industrial policy for catch-up development in the style of Japan and the Tiger economies.

The next two sections discuss the Chinese and Indian economies respectively, exploring in particular their past experience with variants of industrial policies. The similarities of the "China model” to past East Asian experience are explored, while the contrasts of India's development, and the distinction between liberalization and reform are examined. These two major country

\footnotetext{
${ }^{4}$ See, for example, Bardhan (1990) and Amsden (1991)
} 
cases form the basis, in the subsequent section, for a consolidation of recent conceptual ideas, where effective and successful industrial policy is viewed as part of a social contract, creating a pathway to inclusive growth. Regional and other dimensions of inequality are touched on in the discussion of inclusiveness, adding the regional perspective to industrial policy as well. The social contract approach to industrial policy also responds to the critique of government intervention embedded in a trenchant quote attributed (Friedman, 2008) to Ronald Reagan: “The nine most terrifying words in the English language are: 'I'm from the government, and I'm here to help.' " The last section provides a summary conclusion of the arguments of the paper.

\section{What's In a Name?}

The term "industrial policy” can have disparate meanings and connotations. Following what might be characterized as the mainstream or majority perspective, Pack and Saggi (2006) define it to be "any type of selective government intervention or policy that attempts to alter the structure of production in favor of sectors that are expected to offer better prospects for economic growth in a way that would not occur in the absence of such intervention in the market equilibrium.”

Chang (2009) notes that industrial policy can be, and has often been used to mean, any policy that affects industry. This usage conforms to discussions of "agricultural policy" or "monetary policy," which encompass any policies that affect agriculture or monetary variables, respectively. Chang contrasts this broader meaning with the kind of definition given by Pack and Saggi, which he terms "selective industrial policy,” or "targeting." He goes on to discuss the possibility that "general" or "functional” industrial policy, focusing on interventions in education, innovation

and infrastructure, can be distinguished in a sharp manner from the selective or "sectoral" kind. He argues that targeting is inevitable, and simply has to be implemented well - what this might mean in practice is taken up later in this paper.

It is important to clarify that Chang's emphasis on the inevitability of targeting is distinct from any restrictive view of feasible and effective policy instruments. Drawing on the East Asian 
experience, he offers a list of components of industrial policy that extends far beyond subsidies and trade restrictions:

1) coordination of complementary investments

2) coordination of competing investments

3) policies to ensure scale economies

4) regulation on technology imports

5) regulation on foreign direct investment

6) mandatory worker training for firms above a certain size

7) the state incubating high-tech firms

8) export promotion

9) government allocation of foreign exchange

Evaluating this list and assessing its relevance for India and China will also be taken up in subsequent sections of the paper.

Somewhat in contrast to Chang, Rodrik (2004) offers a more sweeping vision of industrial policy. Using the term in the plural, to emphasize the breadth of his definition, as well as the diversity of practical approaches, he essentially equates industrial policies with "policies for economic restructuring.” Explicitly, he states

We will use the term to apply to restructuring policies in favor of more dynamic activities generally, regardless of whether those are located within industry or manufacturing per se. Indeed, many of the specific illustrations in this paper concern non-traditional activities in agriculture or services. There is no evidence that the types of market failures that call for industrial policy are located predominantly in industry, and there is no such presumption in this paper.

Also somewhat in contrast to Chang, Rodrik (2004) de-emphasizes targeting or selectivity as a necessary feature of industrial policy, though he ultimately recognizes that even "horizontal" policies will have differential effects across sectors (Rodrik, 2007). ${ }^{5}$ While industrial policy is a response to market failures (see footnote 2), the precise location and extent of these deviations from optimality is acknowledged to be "highly uncertain.” This perspective leads Rodrik to

\footnotetext{
${ }^{5}$ For example, exchange rate policy will differentially affect tradables and non-tradables.
} 
frame industrial policy as a collaboration between the public and private sectors, in a joint discovery process. Hence, even more strongly than Chang, Rodrik ultimately turns to the nature of the implementation process as an integral part of the definition of industrial policy.

The foregoing summary highlights several important conceptual points with respect to the term “industrial policy.” First, despite differences about the extent and nature of selectivity, or about narrowness versus breadth, the conceptual underpinnings justifying and guiding policy formulation and intervention remain firmly in the realm of externalities and market failure. This is not surprising, since there really is no alternative theoretical foundation. Differences in terminology and in the implications drawn for policy implementation have to do with the nature and extent of market failures.

Second, new conceptualizations of industrial policy, by focusing on the realities of the policy process, incorporate and internalize the broader "state vs. market" debate that has taken place over roughly the last two decades. Again, there are differences in views of state capacity, and the relative roles of the private and public sectors, but there is an acknowledgment that conflicts of interest exist, and have to be dealt with at the heart of the policy process. The middle ground sought by this view stresses "pragmatism" and "balanced strategy," and argues for recognizing that industrial policy is very much in step with the consensus view of the global development agenda.

\section{Industrial Policy and Globalization}

The introduction and the conceptual discussion of industrial policies in the previous section included references to comparative advantage and to policies that affect trade. Trade is important for development strategy, because it potentially allows developing countries to access higherincome markets, to achieve economies of scale, to move up the ladder of sophistication and complexity of products, and to provide competitive discipline. These effects are in keeping with a view of recent economic history as one of increased trade openness as an important positive 
dimension of globalization. ${ }^{6}$ However, there is a possible tension involved in the case for trade liberalization policies, because the theoretical case for free trade is primarily based on static efficiency gains. Several of the policy dimensions enumerated by Chang (2009: see the list in the previous section) as contributing to successful industrial policy in East Asia involve elements of restrictions on trade, particularly inward trade.

In fact, the precursor of more general, externality-based justifications for industrial policy was the $19^{\text {th }}$ century infant industry argument, which made a case for trade protection to allow domestic producers to achieve learning by doing and scale economies without having to face foreign competition that might never let them get off the ground. In the context of standard trade theory based on comparative advantage, ${ }^{7}$ the infant industry argument differentiates between static and dynamic, or current and future comparative advantage, with temporary trade protection allowing a country to evolve comparative advantages in industries or sectors more conducive to long run development and higher living standards.

Baldwin (1969) provided an important analytical critique of the infant industry argument, testing it against modern economic theory. He made the case that the requirements for trade protection for infant industries are quite stringent. Furthermore, potential sources of market failure that could justify policy intervention, such as capital market imperfections, would logically be best tackled by more direct attention, rather than a second-best instrument such as trade restrictions. Subsequent analyses have provided further nuances and justifications for infant industry-type protection, so the theoretical case is not settled in favor or against such policies. ${ }^{8}$

One of the key newer ideas (present in earlier discussions, but less explicitly) is that protection against imports is not enough. A developing economy needs to undergo a structural

\footnotetext{
${ }^{6}$ There is much less consensus, either theoretical or empirical, on the benefits of another dimension of globalization, namely free movement of capital across borders. After the global economic crisis of 2008-09, even the International Monetary Fund, formerly a proponent of capital account openness, has taken a much more cautious position. ${ }^{7}$ Comparative advantage refers to relative productivity comparisons. David Ricardo demonstrated in the $19^{\text {th }}$ century that even if one country is more productive across the board than another country, there can be mutual gains from trade if each country specializes in those industries or sectors where its relative productivity is higher, i.e., where it has a "comparative advantage." The important point is that a country may have an absolute disadvantage across the board, but must, by definition, have a comparative advantage in some industry or sector.

${ }^{8}$ A recent summary of old and new models of the case for or against infant industry protection is provided by Pack and Saggi (2006).
} 
transformation, part and parcel of the process of economic development, and successful exporting promotes a process of discovery with respect to longer-run comparative advantage. This reasoning reinforces the older argument that exports contribute to the development process in more traditional ways, by imposing competitive discipline as well as providing a defense against balance of payments problems. Many economists have identified export promotion as a key feature of the East Asian success story, though they differ in the extent to which they credit "industrial policy" interventions by the respective governments. ${ }^{9}$

The importance of trade in considerations of industrial policy for development finds expression in the framing of policy choices in terms of "comparative-advantage-conforming" versus “comparative-advantage-defying” policies for industrial upgrading. ${ }^{10}$ The first of these perspectives emphasizes the need to upgrade a country's endowment structure (human capital, infrastructure, and so on), with the state facilitating the best use of activities based on the current comparative advantage (e.g., labor-intensive manufacturing). In this view, a country can gradually climb the industrial ladder with the support of a facilitating state. ${ }^{11}$ The second, alternative view argues that adjustment costs and the need for technological catch-up require a greater push from government. To some extent, the differences in these theoretical perspectives also reflect differences in interpretation of the East Asian experience, and the role played by industrial policy in the export-led development of the success stories of the region.

To the extent that comparative-advantage defying industrial policies have been successful in the past, and provide a framework for the future development strategies of other countries, one important aspect of globalization may restrict this possibility. Globalization has included the development of a stronger and broader institutional framework for rules governing multilateral trade. Indeed, the rapid growth of international trade has been a significant part of the growth of

\footnotetext{
${ }^{9}$ For example, Wade $(1990,2003)$ makes a detailed case in favor of strategic government intervention as crucial to East Asian growth. Chang (2002, 2009) takes similar positions. The World Bank study (1993) of the East Asian "miracle" was much less supportive of the conclusion that targeted interventions had positive effects on growth, though it endorsed the positive role of exports. Noland (2007) reaches a conclusion about Japanese policy that is quite reminiscent of the World Bank position in its 1993 study.

${ }^{10}$ These characterizations come from a debate between two economists with different views of industrial policy (Lin and Chang, 2009)

${ }^{11}$ Justin Lin, in Lin and Chang (2009), suggests that the "flying-geese" metaphor used in the context of countries following others up the industrial ladder (Kaur, 2013) is also useful in a purely domestic context, with the "geese" being firms rather than countries.
} 
the world economy, and the rapid development of certain countries. Over time, the rules of the World Trade Organization (WTO) have expanded in scope, so that many domestic policies to promote exports - directly or indirectly - that were used by economies such as Japan, South Korea and Taiwan in the 1960s, 70s, and even 80s, no longer conform to multilateral trade rules. As Rodrik (2004) points out, “Export subsidies are now WTO-illegal (for all but least-developed countries), as are domestic content requirements and other performance requirements on enterprises that are linked to trade, quantitative restrictions on imports, and patent laws that fall short of international standards.” He highlights the need for "policy space” for developing countries. Wade (2003) argues that countries such as Korea and Taiwan continue to pursue strategic government policies that skirt WTO rules, and that these have significant positive benefits for such countries.

Both Wade and Rodrik offer critiques of an approach to trade liberalization that fails to recognize the extreme inequality of initial conditions among developed and developing countries, when new WTO positions push for removal of “distortions.” Indeed, Chang (2002, 2009) goes as far as to compare the WTO’s evolution to “kicking away the ladder” that allowed economies such as Korea and Taiwan to achieve successful industrial upgrading as crucial parts of their development strategies. As an aside, it is also worth noting that arguments for imposing developed country labor and environmental standards or competition policy frameworks through the WTO also ignore unequal initial conditions, as well as being inconsistent in the respect for domestic sovereignty and the arguments made against trade-related industrial policies.

Having argued the case that the WTO's approach may not be allowing adequate policy space for developing countries to pursue industrial upgrading, one must also add a caution that arises from a different aspect of globalization. International production networks, as well as retail-chain buyer-led networks, have become increasingly significant in international trade (e.g., Pack and Saggi, 2006; Kaur, 2013). These developments do not remove the conceptual basis for industrial policy: externalities and adjustment costs will still matter. If anything, the need for coordination, for achieving scale, and for technology upgrading is greater than ever. If a country has the right start, it may be that multinational firms will themselves invest in achieving these goals with suppliers in that country. But how is that start to be gotten? Pack and Saggi (2006), for example, 
argue that the challenges of formulating and implementing effective industrial policies are much greater in a world of complex vertical production networks.

A few observations on capital account openness are also in order. The Asian Tigers grew under a global regime of fixed exchange rates and capital controls. One view that emerged in the 1980s favored capital account liberalization to promote the efficient global allocation of capital. However, capital account openness with flexible exchange rates is incompatible with comparative-advantage-defying industrial policy, and such openness also creates problems for maintain fixed exchange rates. The experience of regional and global financial crises, however, has diminished calls for full capital account liberalization.

To summarize the central discussion of this section, the international component of industrial policy has always been important, because exports support disciplined industrial upgrading. Globalization through greater trade openness has expanded the potential for this policy route. However, globalization has also led to the emergence of vertical production networks that increase the complexity of required policies and the demands on state capacity, thereby making it harder to achieve effective policies. At the same time, the approach of the WTO may not permit adequate recognition of the policy space required by developing countries that need to upgrade their industrial structures. These issues will be explored further in the context of discussions of China and India in the next two sections, as well as in the subsequent attempt to synthesize arguments for "new" industrial policies as pathways to inclusive growth.

\section{The China Model}

In the 1980s, Japan came to be viewed as the first non-Western power to match the economic clout of Western nations. Its economic success was also seen as creating a model for the rest of East Asia, if not all developing countries. While China at the present remains far from Japan's level of development thirty years ago, its size and rapid rise in world trade, especially for manufactured goods, have made it even more of a focus for observers trying to understand its model of development, and lessons that can be drawn from its experience. 
The "China model," therefore, is a convenient shorthand term for the distinctive combination of economic policies and political characteristics that appear to have determined China's economic success. Another common term for this combination has been the "Beijing Consensus," coined by Joshua Ramo (2004), in a play on the longstanding idea of "Washington Consensus." 12 The essence of the China model can be summarized as a combination of political authoritarianism with a version of capitalism that combines some free market competition and some elements of state control. In that broad sense, this is not dissimilar to $19^{\text {th }}$ century Germany, pre-World War II Japan, or indeed, South Korea and Taiwan in the 1960s and 70s. The role of politics is postponed to a subsequent section, in the context of considering inclusive growth, while in this section the role of the state and industrial policy in China's rise is considered.

The original formulation of the Beijing Consensus (Ramo, 2004) is actually of limited analytical value. It talks of three "theorems," which are really broad and disparate themes: innovation, multiple measures of development, and "self-determination." The third of these is very much an offshoot of an older rhetoric of anti-colonialism, while the second is an idea that is broadly accepted, and perfectly compatible with the "orthodoxy" of the Washington Consensus. ${ }^{13}$ Hence, the relevant theme is that of innovation, which is essentially the issue discussed in the previous two sections, of how and to what extent to use government policy to climb the industrial ladder, and to defy existing comparative advantage. Understanding and analyzing the China model is therefore a central task for evaluating the new debate about the role of industrial policy in economic development.

Subsequent discussions of the supposed Beijing Consensus have highlighted its original vagueness, as well as other differences from its Washington counterpart. The vagueness can be viewed more positively, as pragmatism, which is certainly in keeping with how China's leadership seems to have viewed policymaking. Indeed, if one examines the precise policy

\footnotetext{
${ }^{12}$ The Washington Consensus was articulated by John Williamson in the 1980s, and brought together many of the key tenets of neoclassical economics as a roadmap for policymakers. The list of policy principles was (Williamson, 2004): (1) fiscal discipline; (2) restructuring public/social expenditure priorities; (3) tax reform; (4) liberalizing interest rates; (5) competitive exchange rates; (6) trade liberalization; (7) liberalization of inward foreign direct investment; (8) privatization; (9) deregulation; and, (10) secure property rights.

${ }^{13}$ Recently, continuing with the trend for creating catchy labels for sets of policies or policy frameworks, Guimaraes (2011) postulates a "Shanghai Consensus.” This appears to boil down to a stress on China’s assertive commercial diplomacy, however, and is not a full-fledged articulation of a Chinese approach to economic policy.
} 
components of the Washington consensus (footnote 14), at various times, the Chinese leadership has pursued those policies as needed, including fiscal discipline, tax reform, government expenditure priorities, trade and foreign investment liberalization, and security of private property rights. On the other hand, financial sector and exchange rate policies have deviated much more from neoclassical economic orthodoxy. In reality, the Washington consensus also embodies some pragmatism, and acceptance of the limits of the market, so much of the difference in policymaking approach might be viewed as a matter of degree. In fact, a case can be made that China's policy mix has moved steadily toward incorporation of many Washington consensus principles (Yao, 2010). ${ }^{14}$ Again, the exceptions are financial sector management and industrial policy.

It is impossible to do justice in a short space to all aspects of China's development experience over the last three decades, but one can provide a brief overview as a prelude to a discussion of China's approach to industrial policies. In addition to the selective embrace of some features of capitalism, one can note the important role played by foreign direct investment (particularly from “greater China,” including Hong Kong and Taiwan), regional clusters as export processing zones, the entrepreneurialism of regional and local government officials, and levels of literacy and health that were probably above the average for countries with similar initial income levels. China has also achieved extraordinarily high rates of saving and investment, particularly for its income level. Enormous investment has gone into physical infrastructure, and now the Chinese government is attempting to achieve similar gains in human capital, by upgrading higher education.

The mechanism for channeling savings in China has been financial repression, contrary to the recommendations of the Washington consensus. Households have subsidized corporations through the tax system, exchange rate management, and controls on prices (particularly including interest rates on savings). ${ }^{15}$ Real wages have been kept low, and the share of household income and consumption in the economy has actually declined in recent years (Prasad, 2009). Regional

\footnotetext{
${ }^{14}$ Yao (2010) also addresses issues of political viability of the current policy mix, and this will be the subject of the penultimate section of this paper.

${ }^{15}$ This argument is attributed to Michael Pettis in Kumar (2009), though it can also be found in other analyses of the Chinese experience. See, for example, Yao (2011).
} 
inequality and income inequality have also probably fed into these trends in the overall distribution of national income. These issues will be discussed in the penultimate section of the paper.

Initially, China's growth surge began with labor-intensive manufacturing consistent with its level of income and comparative advantage at the time. However, it has been argued that one of China's distinguishing features has been its pursuit of structural change through exports. In particular, Rodrik (2006) states, “Government policies have helped nurture domestic capabilities in consumer electronics and other advanced areas that would most likely not have developed in their absence. As a result, China has ended up with an export basket that is significantly more sophisticated than what would be normally expected for a country at its income level. This has been an important determinant of China's rapid growth.”

The basis for Rodrik's conclusion is a detailed analysis of the composition of China's exports. To be sure, China exports labor-intensive manufactures that are consistent with its current factor endowments and its levels of income and wages. But it also exports many more sophisticated goods. One therefore has to have an empirical measure of overall export sophistication. Using an index of export sophistication based on typical export profiles at different levels of country per capita income, Rodrik finds that, even as early as 1992, China's export pattern was similar to that of a country with six times its per capita income. That multiple has gone down somewhat (presumably partly because of China's rapid growth), but still remains high: China is a very strong outlier among all developing countries.

There are qualifications that can be made to Rodrik's basic empirical analysis, including the fact that export data may overstate the sophistication of the actual processes used, if what is being done within China is assembly of high-value imported components into complex final products. Nevertheless, the numbers are striking enough to suggest that China has, to some extent, successfully pursued a comparative-advantage-defying strategy. In this regard, Rodrik is also careful to check whether the correlation between export sophistication and growth rates is actually the result of a causal relationship from exports to growth, and he finds some evidence to support that hypothesis. 
The implications of this analysis are that "what you export matters" not just how much, that China's growth success cannot be attributed just to high savings and investment rates, and that a country may successfully accelerate its climb up the ladder of industrial sophistication. The empirical analysis does not, however, directly assign the credit for this process to government policy. For this, one has to rely on case studies of Chinese experience. Certainly, many of the elements of policy listed by Chang (see section 2 above) have been used by China in its industrialization efforts. Building on a case study by the McKinsey Global Institute (McKinsey \& Co., 2003), Rodrik focuses on the consumer electronics industry and argues that China has used targeted foreign joint ventures, technology transfer requirements and consolidation of domestic firms as policy tools for building various facets of a domestic consumer electronics industry. Linden (2004) analyses the Chinese use of standard setting to create advantages for domestic firms vis-à-vis foreign competitors. On the other hand, Lin (in Lin and Chang, 2009) offers a more cautious assessment of the ability of Chinese policymakers to seriously defy existing comparative advantage.

Even if it is acknowledged that China's economic success has included more traditional laborintensive manufacturing and exports (Kaur, 2009, and references therein), and that targeting has not always succeeded (Huchet, 1997; Kraemer and Dedrick, 2001), it is reasonable to assign some positive role to government policy in shaping the evolution of the industrial sector. Certainly, China's political and economic leadership takes the view that industrial policy matters. In October 2010, the Communist Party of China approved guidelines for the $12^{\text {th }}$ Five-Year Plan, covering the period 2011-15. Among the themes of the guidelines is a clear nod to industrial policy that is very much in the mould of past East Asian policymaking. According to a consulting firm report (APCO Worldwide, 2010):

Strategic Emerging Industries: No longer content with being considered the “world's factory," Chinese planners have included several preferential tax, fiscal and procurement policies designed to develop seven “Strategic Emerging Industries” (SEIs). Planners hope these industries will become the backbone of China's economy in the decades ahead, and they have been chosen sectors where Chinese corporations are expected to succeed on a global scale. The seven industries are biotechnology, new energy, high-end equipment 
manufacturing, energy conservation and environmental protection, clean-energy vehicles, new materials, and next-generation IT. The government is reportedly prepared to spend more than RMB 4 trillion on these industries during the 12th FYP period, with an aim to increase SEI's contribution from today's approximately 5 percent of GDP to 8 percent by 2015 and 15 percent by 2020 .

This indicates that a focus of policy clearly continues to be the "innovation" aspect of the socalled Beijing Consensus. On the other hand, despite the aspect of targeted promotion of sectors or industries, it is certainly possible that implementation will be more in the nature of Rodrik's “discovery process," with the private sector taking an important role.

\section{India: Liberalization vs. Reform}

While China made a dramatic change in policies to pursue economic growth, India's path has been less clearly defined. It is true that 1991 saw a significant shift in Indian economic policy. The Indian rupee was devalued, trade barriers were reduced, and much of an extensive system of industrial licensing controls was dismantled. However, it is fair to say that India did not immediately embrace the maxim of Deng Xiao Ping, that "to get rich is glorious.” Liberalization of controls was not followed by quick or certain institutional reforms that might be expected to create a high growth environment. Nevertheless, India has grown rapidly in the last two decades, and its story is complex and somewhat unusual.

India became independent in 1947, and followed a strategy of "governing the market," including infant industry protection, import substitution, and industrial policy more generally. However, it departed from the East Asian model in its failure to focus on export promotion or technological catch up through technology imports or foreign direct investment. The exchange rate was overvalued, and inward flows of capital and technology were severely curtailed. Thus, in terms of the list of policy instruments enumerated by Chang (section 2 above), India used some, but not others, suggesting that what matters is the combination of instruments, not just individual elements of policy. While private property was permitted (unlike China) and disasters like China's Great Leap Forward were avoided, India lagged behind China in basic health, nutrition and education indicators, while matching it in per capita income until China's 1978 policy 
reversal. The acceptance of private property was tempered by a deep mistrust of business, and of market forces: price controls were commonplace.

The Indian apparatus of economic policymaking came to be dominated by Five Year Plans, modeled originally on the Soviet version, but without the full array of command and control devices. Even after liberalization, indicative planning has continued as a staple of India's economic policy framework, although it is now mostly a budgeting and strategic thinking exercise. While private sector firms continued to operate, state-owned firms were favored in sectors viewed as core to industrialization, such as steel, cement, transportation and a range of engineering goods. A major step taken in 1969 toward state-led industrialization was the nationalization of the banking industry.

Despite the inefficiencies, rent-seeking and relatively slow growth of the 1960s and 70s, a case has been made that various facets of India's industrial policies laid the foundations for future growth. Nationalization of banks apparently increased rural lending and lending to the poor (Burgess, Pande and Wong, 2005; Basu, 2008) even if public sector banks were not efficient (Banerjee, Cole and Duflo, 2004). Bank nationalization may also have contributed to an increase in the savings rate, private equipment investment, and infrastructure development (Sen, 2007). The investments in heavily subsidized higher education created a skilled workforce that was instrumental in the rise of India's software industry.

Some analyses have argued that India's growth rate began to accelerate in the late 1970s or 1980, well before the liberalization of 1991, and as a result of India's state-led growth strategy. Several authors (e.g, Rodrik and Subramanian, 2004; Kohli, 2006) have focused on various aspects of the 1980s, when there was a policy shift away from hostility to "big business," and the beginnings of liberalization in the telecommunications sector (albeit in a world where the technologies were very far from today's completely digital networks). The argument made in these cases is that it was more business-friendly attitudes, rather than market-oriented liberalization, that changed India’s growth path. On the other hand, Panagariya (2008) makes a case for 1988 as a "break year," in growth performance, although the growth acceleration at that stage was unsustainable because it led to a balance of payments crisis. 
Aside from the difference in clarity of policy shifts, India also differs from China in the sources of growth. China has, in many respects, followed the "East Asian” model, not only in terms of a corporatist state, but especially in its emphasis on export-oriented manufacturing. India's manufacturing sector, in contrast, has not had the same kind of impressive growth. The share of manufacturing in India's GDP has not changed much, and the services sector has been the leading source of growth (e.g., Singh, 2007). The services sector is quite heterogeneous, and includes transportation, trade and even government services. One of the most dynamic components of the sector has been business services, including software development.

India's software sector stands out as its most obvious global success story. It has been almost entirely export-focused, and been a major contributor to easing India's balance of payments constraints since the 1990s. Its growth rate has been spectacular by any standards. In the early days of the software industry's rise, concerns were expressed about the nature of the work being performed - low-end testing and programming - but the leading firms successfully upgraded their skills and have provided more and more sophisticated services over time. In many ways, the software sector in India is a classic example of industrial upgrading.

It has been argued that the foundations of success for India's software sector were laid by the industrial policies of the 1960s and 70s - India had a relatively large pool of trained engineering graduates (whose education had been heavily subsidized) and a cluster of public sector science and technology-oriented organizations in Bangalore, where the software industry took off. An alternative view is that the success was accidental, and not the result of deliberate targeting. India’s government had envisaged developing a computer hardware industry, and provided investment in that, but hardware was not at all a component of the growth of India's information technology (IT) industry. Nor was it the case that the engineering graduates who initially went into the industry were specifically trained in computer science or even electronics - chemical and mechanical engineers also were recruited. One of the founders of Infosys, an iconic successful IT company, has also emphasized that the company's success was aided by its freedom from the stifling controls that formed part of India's industrial policy - they were able to fly under the 
radar because software was not even recognized as an "industry" to be specifically regulated (Murthy, 2004).

While India’s software industry may not survive as an example of traditional industrial targeting, its experience is somewhat consistent with the newer conceptualization of industrial policy articulated by Rodrik, and discussed in earlier sections. Once the success of software became apparent, India's government policies began to veer toward providing support in an implicit partnership. Substantial reform of the telecommunications sector, providing the infrastructure for export of software services, was achieved beginning in the 1990s. Favorable tax treatment was accorded to software exports, and technology parks developed to create clusters of exporting firms. The Indian Diaspora also played a role in bringing in investment, technology and policy ideas. In essence, the trajectory of the software industry was similar to what China achieved much more broadly and on a much larger scale with manufacturing.

A major distinction between India and China has been in the skill-intensity of their export sectors. Software development requires a much higher level of education and skills than factory assembly lines, and lower levels of labor intensity. While the success of software services spilled over to a much broader class of business services (IT-enabled services), including call centers, medical record processing, and analytical services, even these require higher education, and language skills not possessed by the vast majority of India's population. Even though, in the case of China, Rodrik (2006) emphasizes the relative sophistication, on average, of its exports, that country has also combined upgrading with the creation and expansion of a large base of laborintensive manufacturing. That achievement remains largely absent so far from India's economic development.

The causes of this situation for India will be taken up in the next section. The symptoms are summarized here. India's employment generation - the elasticity of employment with respect to growth - has continued to be relatively low, although it picked up in the last decade, vis-à-vis the 1990s. Composite measures of "economic freedom" or, more specifically, the ease of doing business in India (the World Bank index, in particular) continue to rank India very low, with no upward movement in its rank in the last few years. Analyses of industrial dynamics (Krueger, 
2007; Alfaro and Chari, 2009) suggest that large incumbents continue to dominate their industries, with relatively slow or even no replacement of old, inefficient firms by new entrants.

Of course, there are exceptions, and oligopolistic structures were not inconsistent with the development of labor-intensive manufacturing in East Asian successes such as Japan and South Korea. Hence, the Indian situation is not necessarily one of unmitigated gloom. If anything, even China still faces challenges of generating additional employment and sustaining its growth. The next section therefore draws on the experiences and situations of the two giants, China and India, to develop an integrated case for a "new" approach to industrial policy.

\section{Pathways to Inclusive Growth}

History and recent case studies suggest that industrial policy has been an important aspect of many successful development strategies, even if this conclusion is difficult to support with hard statistical analysis. Industrial policy in this view is not narrow targeting or "picking winners," though every policy has potentially differential effects across sectors. The essence of the conceptual justification for industrial policy is that market failures are common, particularly in developing countries. The cases of India and China illustrate a range of experience with respect to industrial policy, with neither country having hewed closely to the Washington consensus of light-handed government participation in the economy.

The pre-liberalization Indian case, in particular, illustrates some of the pitfalls of industrial policy, as well as benefits. Government interventions can not only fail to correct market failures, but introduce their own distortions. Industrial policies can create rents that are defended by vested interests, leading to stifling of innovation rather than encouraging it. The Indian case also illustrates the possibility of discovery of new opportunities, and the need to adapt to these: India sought to develop capabilities in engineering, including computer hardware, but the information technology opportunity that presented itself came in software, in ways that would have been difficult to foresee even a few years earlier. 
More generally, the Indian and Chinese growth experiences illustrate the possibilities of growing inequality along with rising average levels of income, and the challenges that such inequality poses for political and social stability. ${ }^{16}$ The management of inequality is often viewed solely as a component of social policy, through redistributive tax policy or transfers, rather than having anything to do with industrial policy. If anything, social policies to ameliorate inequality are viewed as potentially detrimental to growth, especially in some developed countries. However, an alternative view, one that is probably more relevant to developing countries, is that growth that is sustainable in the long run has to be inclusive enough, both to upgrade and utilize a country's human resources, and to avoid internal political conflict. This perspective is the punch line of this paper, that successful industrial policy has to be part of a social contract.

The remainder of this section expands on this key idea, of industrial policy for inclusive growth. First it discusses what it means to for industrial policy to be part of a social contract, relating this formulation to earlier ideas of the developmental state, and of "embedded autonomy.” Second, we draw out the implications of this approach for domestic regional policy. Third, we relate domestic and international trade aspects of industrial policy, particularly in the context of the rise of global vertical production networks. Finally, this section discusses some implications for future possible policy approaches in China and India.

There are several different articulations of ideas related to that of a social contract. Wade (2003) uses the term "developmental state,” which originates from the work of Johnson (1982) on Japan’s economic development. What makes a state “developmental”? Wade's analysis is framed in terms of "relationship" or "alliance” capitalism, while recognizing that this can degenerate into "crony capitalism.” A more precise view of what the "alliance” must entail for successful development policy is provided by Evans (1995):

The internal organization of developmental states comes much closer to approximating a Weberian bureaucracy. Highly selective meritocratic recruitment and long term career rewards create commitment and a sense of corporate coherence. Corporate coherence gives these apparatuses a certain kind of "autonomy." They are not, however, insulated

\footnotetext{
${ }^{16}$ The observation that growth first leads to increasing and then decreasing inequality as an empirical regularity is due to Simon Kuznets, and often known as the Kuznets curve. However, the extent and inevitability of this pattern are not well understood.
} 
from society as Weber suggested they should be. To the contrary, they are embedded in a concrete set of social ties which binds the state to society and provides institutionalized channels for the continual negotiation and renegotiation of goals and policies. Either side of the combination by itself would not work. A state that was only autonomous would lack both sources of intelligence and the ability to rely on decentralized private implementation. Dense connecting networks without a robust internal structure would leave the state incapable of resolving "collective action” problems, of transcending the individual interests of its private counterparts. Only when embeddedness and autonomy are joined together can a state be called developmental.

This apparently contradictory combination of corporate coherence and connectedness, which I call "embedded autonomy," provides the underlying structural basis for successful state involvement in industrial transformation. (Evans, 1995, Chapter 1) Rodrik (2007) views Evans' framework as capturing the right model for industrial policy, "a model of strategic collaboration and coordination between the private sector and the government with the aim of uncovering where the most significant bottlenecks are, designing the most effective interventions, periodically evaluating the outcomes, and learning from the mistakes being made in the process."

These formulations focus on the state and business, rather than society, and neglect the question of social legitimacy, captured more explicitly in the idea of a social contract. One can argue that Japan, South Korea, Taiwan and the city-states of Hong Kong and Singapore, all had preconditions that shaped industrial policy within a broader social contract. Relatively homogeneous populations, equitable distributions of income and of education and health indicators, all reinforced the direction of industrial policy toward growth that created unskilled and semi-skilled employment, and shared the fruits of growth (Birdsall, Ross and Sabot, 1995). ${ }^{17}$

\footnotetext{
${ }^{17}$ Wade (2003), commenting on his original 1990 analysis, remarks that his "book explores the sources of state motivation, state strength, and policy credibility. Missing, though, is analysis of the external economies of human capital that are a major source of increasing returns to production in Taiwan and other East Asian countriesmicroanalysis of firm capabilities and corporate governance, and mesoanalysis of interfirm input-output networks, factor markets, and tacit knowledge.” This is not quite as broad as the idea of a social contract, including civil society linkages, but does acknowledge the different layers of interaction required for successful economic development.
} 
Looking at China, its trajectory may still follow this path. Its governmental structures and methods of reaching consensus are not dissimilar to other East Asian successes that preceded it. The main, and dominating, difference is China's size and geography, which has necessitated a very different regional strategy. Export-oriented growth was concentrated in well-demarcated coastal regions, leading to a substantial increase in regional inequality. The regional concentration was also initially influenced by the political objective of geographically containing what was then a radical experiment, of shifting quickly from collectivism to capitalist enterprise. The regional issues are discussed later in this section. China's size has also meant that it had a much larger body of rural labor to absorb than the earlier East Asian Tigers, and this contributed to a policy of keeping wages low to fuel continued export growth. At its heart, though, China's leadership probably has a well-defined sense of its population as a national entity, and its legitimacy as deriving from that population as a whole.

India's social contract has been much more tenuous. Indian identities are considerably more heterogeneous, and also variable across regions. India's leadership has either been successors of colonial-era models, or had strong regional identities. Furthermore, vertical divisions in Indian society have always been sharper than in China. One symptom of these divisions has been greater inequality in human development outcomes such as basic health and education, and the failure to create avenues for large-scale employment outside agriculture. The difficulties of managing ruling coalitions in such a diverse democracy, and possibly also lingering ideological suspicion of business may have contributed to India's failure to integrate industrial policy into a “developmental state,” or a broad-based, development-supporting social contract, despite avowed objectives of poverty alleviation and inclusive growth.

The size of China and India creates challenges for Evans' ideal of “corporate coherence.” Centralization is not possible to the degree that is achievable in smaller countries. Coordinating layers of governance in both countries adds an extra dimension to the social contract and industrial policy formulation. China's initial experiment with capitalism was highly concentrated in particular provinces and even zones within those provinces. Provincial and local governments, given the opportunity, raced ahead where they could. The central government then had to reassert control, including reforming the tax system to gain more direct control over revenues, 
rather than relying on the provinces to collect and share taxes. However, the unevenness of the pattern of development continued, favored by the initial differential treatment, and the continued emphasis on export-led growth. The coastal provinces that have been the centers of manufacturing for China have become much richer than their inland counterparts.

India's regional inequalities have been determined less by government policy, and more by earlier history. Well before independence, the southern states began to undergo a civil society movement by lower castes for higher social status. After independence, this translated into political power at the state (provincial) level, and policies that tended to support greater social equality, including in areas such as access to education. These states were therefore better poised for growth after liberalization. The fact that the software industry took off in Bangalore, in the south, was also a significant factor in the recent pattern of regional development. In other cases, such as those of the western states, longstanding strengths in finance and certain other industries also conveyed advantages after liberalization. Meanwhile, many of the poorer states continued to lack the pre-conditions for strong growth: literacy rates, health indicators and physical infrastructure lagged well behind other areas. India's pattern of regional development has therefore been somewhat less deliberately determined by policy than China's, and it may be harder to alter this pattern through deliberate policy than is likely the case for China.

Regional balance cannot be overdone. Appalachia is still a relatively backward part of the United States, because of its topography. On the other hand, that country's northeast corridor, from Washington, DC to Boston, represented a pattern or regional development with dense linkages and complementary specializations that emerged early and endured unchallenged for a long time. To the extent that India and China will also follow this path, their policies have to accommodate massive migration and expansion of cities into metropolitan agglomerations. An important dimension of regional industrial policy will be weighing the costs and benefits of reducing such spatial concentration by developing satellite industrial clusters through tax incentives and investments in telecommunications, transportation and housing infrastructure in those places. In some cases, private firms themselves seek these alternatives, to take advantage of lower wages and land costs. 
A useful theoretical perspective on these spatial characteristics of industrial policy is offered by Wade (2003), which also sheds light on the factors that can support an effective social contract: An economy with high internal integration has a well-filled input-output matrix-a dense set of links between sectors (a high level of sectoral articulation between, e.g., rural and urban, and consumer goods and intermediate goods), and a structure of demand such that a high proportion of domestic production is sold to domestic wage earners (a high level of "social" articulation between wages, consumption, and production). Export demand is not the main source of economic growth. Robust political coalitions between capitalists and employees become possible in this type of economy, because capitalists, employees, and the government recognize a common interest in wages as a source of sales and economic growth, not just as a cost of production. (Wade, p. xlviii)

The above argument is not made explicitly in terms of regional characteristics of development, but must include some element of a regional dimension for a large country such as China or India. One can also note the trade-off between economies of agglomeration, favoring spatial concentration, and the benefits of extending the developmental coalition and economic inclusiveness outside just a few initial clusters.

The discussion in Wade (2003) goes on to consider the possible conflicts and complementarities between internal and external integration. The approach presented there seems to be a combination of import substitution and export promotion, very much in the classic mould of East Asian industrial policy. Kaur (2013) highlights, and discusses in some detail, the development of global production networks, which have been created by outsourcing of various stages of production of a range of complex products, particularly in electronics. There are several implications of this phenomenon for the design and conduct of industrial policy. First, there is the possibility of occupying smaller niches in the value chain, since there has been more disintegration of the stages of production across firms and geographic boundaries. Second, the possibilities of upgrading are enhanced, to the extent that upgrading can involve smaller steps assembling a larger set of components, perhaps, or adding production of some components to assembly. Both these possibilities enhance opportunities and the scope for policy. 
On the other hand, production networks may be more difficult to penetrate - existing ties based on reputation and relationships may be hard to disturb for new entrants. Policy decisions are also complicated by the much greater array of choices. Rodrik's "process of discovery” becomes more complex and uncertain, and the information exchange and level of trust between the public and private sector correspondingly has to be higher.

It is useful to realize, however, that from an economic point of view, external and internal integration are not any different. Industrial policy that promotes export capability in assembling a particular final product may seek to upgrade by moving on to making some of the components that go into the final product. However, the simpler assembly stage does not have to be lost to another country - it may simply move within the country to a lower-cost location. For this to happen, industrial policy has to anticipate this possibility, and weigh its costs and benefits. A Singapore does not have any hinterland, and a Taiwan or South Korea is also relatively small, but the regional options for an India or China are many and diverse. Conceptually, therefore, the pure economics of geographically dispersed production networks does not have to be closely tied to national boundaries.

The political implications of different types of upgrading, however, can be very different. If export-oriented manufacturing is already concentrated in some regions, and upgrading means shifting simpler stages of production to other countries that offer lower costs, internal integration is lost, as are its benefits as articulated by Wade (2003). Managing this aspect of industrial policy is therefore an important challenge facing both China and India. As outlined in the previous two sections, both countries have followed very different trajectories, but both face the need to make future growth more inclusive. Inclusive growth is necessary to sustain political legitimacy, even though the mechanism of legitimacy is different in democratic India and authoritarian China. Industrial policy as a method for driving structural change in the economy and upgrading capabilities also has to make sure that less-developed portions of a country, especially a large and diverse one, are included somewhere in the flock of flying geese. ${ }^{18}$

\footnotetext{
${ }^{18}$ The interpretation and applicability of this metaphor are discussed in detail in Kaur (2013). Typically, different geese are taken to be different countries. Here one is extending the metaphor to different regions within a country, or even different sections of society.
} 
One has to remember that the discussion of the geographic dimensions of industrial policy, as part of a pursuit of inclusive growth, is ultimately tied to the need to generate productive employment throughout a country. China has followed the classic model of pursuing laborintensive manufacturing for development and growth. However, it has sought to focus on export demand rather than domestic consumption. This focus has also contributed to increased regional inequality, as has a policy of keeping wages and the exchange rate lower than a possible market equilibrium. Much of India’s employment growth has come outside the formal manufacturing sector, either in services or in the "informal” sector. In that sense, India's divergence from a traditional path of inclusive growth is more striking, and less driven by regional inequalities or export-led growth. To the extent that India has to restructure its industrial landscape more dramatically, while facing a demographic bulge in its working-age population, its coming policy challenges may be greater than China's.

In closing this section, one can relate its thesis to Ronald Reagan’s quote, given in the introduction, implying that government intervention is counter-productive to economic progress. The argument presented here recognizes that government intervention in general, and industrial policy in particular, does not always work. However, the key idea is that if government is truly "of the people," through a social contract, then it will also be "for the people," rather than a blundering Leviathan. Arguably, the processes set in motion by Reagan’s policies have unraveled much of the United States’ own social contract, forged through the first half of the $20^{\text {th }}$ century, without providing a viable alternative. Neither China nor India is likely to sustain its growth by going down that path.

\section{Conclusions}

What are the central arguments of this paper? The first is that industrial policy for economic development has worked in the past, and can work in the future. An important component of this assertion is how one understands industrial policy. It has to be more than top-down targeting or “picking winners," encompassing collaboration with the private sector, and openness to discovery of new opportunities for innovation and development. This argument is distilled from 
a considerable body of recent work, which seeks to counterbalance a view that had emerged in the 1980s, downplaying the capabilities of government as a driver of economic progress.

A second thread that runs through the paper is that globalization has changed the economic landscape, creating global production networks that can make the task of industrial policy more complex. The paper also discusses the role of global trading rules, and notes the dangers of extending those in ways that unfairly constrain new industrializers among the community of nations. The new academic perspective on industrial policy encompasses these issues. This paper makes a contribution by pointing out the connections between the global and the regional, for large countries such as China and India.

The third, and most central and novel argument presented in this paper is the importance of the social contract within which any set of industrial policies are formulated and implemented. In the literature, arguably, the notion of a social contract as a prerequisite for successful industrial policies is not fully articulated, and this paper begins to fill that gap. The applicability and relevance of this perspective are illustrated here with a detailed comparative consideration of India and China's past experiences with economic policies (including each country's version of industrial policies) and the future challenges that each country faces in pursuing sustained high growth that will bring one third of the world's population up to reasonable levels of living standards. The arguments presented in this paper are therefore central to debates about the role of the government in society more broadly, and in economic development in particular. For the billions who live in developing countries, Ronald Reagan's quip, about the dangers of government help, indeed raises serious issues, which this paper has addressed.

\section{References}

Alfaro, Laura, and Anusha Chari, 2009, India Transformed? Insights from the Firm Level 19882007, NCAER-Brookings India Policy Forum

Amsden, Alice H., 1991, Diffusion of Development: The Late Industrializing Model and Greater East Asia, The American Economic Review, Vol. 81, No.2, May, pp.282-6 
APCO Worldwide, 2010, China's $12^{\text {th }}$ Five-Year Plan, http://www.apcoworldwide.com/content/PDFs/Chinas_12th_Five-Year_Plan.pdf

Baldwin, Robert, 1969, “The Case against Infant Industry Protection.” Journal of Political Economy,77(3):295-305.

Banerjee, Abhijit, Shawn Cole, and Esther Duflo, 2005, Banking Reform in India, India Policy Forum, 1, 273-323.

Bardhan, Pranab, 1990, Symposium on the State and Economic Development, Journal of Economic Perspectives, Vol. 4, No. 3

Basu, Kaushik, 2008, The Enigma of India’s Arrival: A Review of Arvind Virmani’s Propelling India: From Socialist Stagnation to Global Power, Journal of Economic Literature, 46, 3, 396406.

Birdsall, Nancy, David Ross and Richard Sabot, 1995, Inequality and Growth Reconsidered: Lessons from East Asia. World Bank Economic Review, Vol. 9, No. 3, pp. 477-508.

Burgess, Robin, Rohini Pande and Grace Wong, 2005, Banking for the Poor: Evidence from India, Journal of the European Economics Association Papers and Proceedings, Vol. 3 (2-3), pp. 268-278, April - May.

Chang, Ha-Joon, 2002, Kicking Away the Ladder: Development Strategy in Historical Perspective, Wimbledon Publishing Company, London

Chang, Ha-Joon, 2009, Industrial Policy: Can We Go Beyond an Unproductive Confrontation? ABCDE (Annual World Bank Conference on Development Economics), Seoul, South Korea, 2224 June.

Evans, Peter, 1995, Embedded Autonomy: States and Industrial Transformation, Princeton, NJ: Princeton University Press.

Friedman, Thomas, 2008, “No Laughing Matter,” Sep $20^{\text {th }}$, New York Times 
Guimaraes, Conrad, 2011, A Shanghai Consensus?, East Asia Forum, April 2, http://www.eastasiaforum.org/2011/04/02/a-shanghai-consensus/

Huchet, Jean-Francois, "The China Circle and Technological Development in the Chinese Electronics Industry,” in B. Naughton, ed., The China Circle: Economics and Electronics in the PRC, Taiwan, and Hong Kong, Washington, DC: Brookings Institution Press, 1997.

Johnson, Chalmers, 1982, MITI and the Japanese Miracle: The Growth of Industrial Policy, 1925-1975, Stanford, CA: Stanford University Press.

Kaur, Inderjit N., 2013, Are the Geese Still Flying? Catch-up Industrialization in a Changing International Economic Environment, forthcoming in Handbook of the Economics of the Pacific Rim, Ed. Inderjit N. Kaur and Nirvikar Singh, New York: Oxford University Press.

Kraemer, Kenneth L., and Jason Dedrick, “Creating a Computer Industry Giant: China’s Industrial Policies and Outcomes in the 1990s," Center for Research on Information Technology and Organizations, UC Irvine, 2001.

Krueger, Anne, 2007, The Missing Middle, Stanford Center for International Development, Working Paper 343, Stanford University.

Kohli, Atul, 2006, "Politics of Economic Growth in India, 1980-2005, Part I: The 1980s," Economic and Political Weekly, April 1,

Kumar, Rajiv, 2009, China’s Investment Story, The Mint, November 17, http://www.livemint.com/2009/11/17211210/China8217s-investment-story.html

Lin, Justin Yifu, and Ha-Joon Chang, 2009, Should Industrial Policy in Developing Countries Conform to Comparative Advantage or Defy it? A Debate Between Justin Lin and Ha-Joon Chang, Development Policy Review, 27, 5, 483-502

Linden, Greg, 2004, China Standard Time: A Study in Strategic Industrial Policy, Business and Politics, 6 (3), Article 4 
McKinsey Global Institute, 2003, New Horizons: Multinational Company Investment in Developing Economies, San Francisco, October

Murthy, N. R. Narayana. 2004, “The Impact of Economic Reforms on Industry in India: A Case Study of the Software Industry.” In India's Emerging Economy: Performance and Prospects in the 1990s and Beyond, ed. Kaushik Basu, 217-22. Cambridge and London: MIT Press.

Noland, Marcus, 2007, Industrial Policy, Innovation Policy, and Japanese Competitiveness, Peterson Institute for International Economics, Working Paper 07-4, Washington DC.

Pack, Howard, and Kamal Saggi, 2006. Is There a Case for Industrial Policy? A Critical Survey. The World Bank Research Observer 2006 21(2): 267-297.

Panagariya, Arvind, 2008, India: The Emerging Giant, New York: Oxford University Press.

Prasad, Eswar, 2009, Rebalancing Growth in Asia, NBER Working Paper 15169, Cambridge, MA: National Bureau of Economic Research

Ramo, Joshua, 2004, The Beijing Consensus, London: The Foreign Policy Centre

Rodrik, Dani, 2004, Industrial Policy for the $21^{\text {st }}$ Century, Working Paper, John F. Kennedy School of Government, Harvard University.

Rodrik, Dani, 2006, What's So Special About China’s Exports? China \& World Economy, vol. 14. no. 5, September-October, 2006, 1-19.

Rodrik, Dani, 2007. Normalizing industrial policy. Paper prepared for the Commission on Growth and Development. http://ksghome.harvard.edu/ drodrik/Industrial\%20Policy\%20_Growth\%20Commission_.pdf

Rodrik, Dani, and Arvind Subramanian, 2004, From “Hindu Growth” To Productivity Surge: The Mystery of the Indian Growth Transition, Working Paper, John F. Kennedy School of Government, Harvard University.

Sen, Kunal, 2007, “Why Did the Elephant Start to Trot? India’s Growth Acceleration Reexamined.” Economic and Political Weekly, 42(43): 37-47. 
Singh, Nirvikar, 2007, Services-Led Industrialization in India: Assessment and Lessons, in Industrial Development for the 21st Century: Sustainable Development Perspectives, ed. David O’Connor, New York: UN-DESA, pp. 235-291

Wade, Robert, 1990, Governing the Market, Princeton, NJ: Princeton University Press

Wade, Robert, 2003, Governing the Market, Introduction to the 2003 Paperback Edition:

Creating Capitalisms, Princeton, NJ: Princeton University Press

Williamson, John, 2004, “A short history of the Washington consensus.” Proceedings from

Forum 2004: From the Washington Consensus towards a new Global Governance. Barcelona.

World Bank, 1993, The East Asian Miracle: Economic Growth and Public Policy, Washington DC: World Bank

Yao, Yang, 2010, The End of the Beijing Consensus, Foreign Affairs, Snapshots, February 2, http://www.foreignaffairs.com/articles/65947/the-end-of-the-beijing-consensus

Yao, Yang, 2011, China's Export-Led Growth Model, East Asia Forum, February 27, http://www.eastasiaforum.org/2011/02/27/chinas-export-led-growth-model/ 